\title{
ASSESSING AND IMPROVING RECOMMENDATIONS FOR LOCAL POWER QUALITY EFFICIENCY FOR INDUSTRIAL PLANTS WITH THE HELP OF REAL DATA
}

\section{Levent Kulıç}

\author{
Şişecam Science, Technology and Design Center, Turkey
}

lkilic@sisecam.com

\begin{abstract}
The Turkish grid system is under big dynamic changes. Renewables are continuously increasing, distribution privatization was completed. There are many participants of electricity system of Turkey. To synchronise all these needs scientific rules and regulations to be obeyed.

On the other hand, although many rules, there is no any statistical data about how system operates effectively. What are the industrial plants faced with? Industrial plants connected to the national distribution or transmission grid at medium voltage level are really exposed to various grid events that affect firstly production efficiency, equipment, system failure and unexpected malfunctioning.

Without data, there is no way to analysis and make clear definition of grid events. Recorded data for a long time in the point of common coupling will be used to evaluate existing status and to estimate next ones.

In this paper, comparative power quality comparison will be analysed for 12 industrial plants distributed localized at five different industrial grid points. It is aimed to the seven different regions of our country compared to the facilities connected to the national system and compare them with a point from abroad. With this study, Turkish power quality intensity is realized by site data for next care of private sectors, private electric companies and industrial plants, and to give numerical data to literature.
\end{abstract}

Keywords: power, quality, grid, events, statistic, sag

\section{Introduction}

In order to achieve objectives as continuity and security of the supply, some problems have to be issued together by system operators and the other users based on real data. Some countries have issued dedicated grid codes for connecting the all kind of plants to the electrical grid addressed to transmission or distribution system. Turkish grid code is based particularly European ones in conjuction with The Institute of Electrical and Electronics Engineers (IEEE). In Turkish grid code these requirements haven't focused on power quality and fault ride through 
capability of industrial plants. Grid disturbances have deeply negative impact on industrial plants.

There are a variety of events in the grid, most of them related to the grid voltage. These events are characterized by a change in amplitude and durations from milliseconds to hours. Based on these amplitude and duration, voltage events are classified in different ways by standard methods [1].

There are a number of power quality problems in the present-day fast-changing electrical systems. The main causes of these power quality problems can be classified into natural and man-made in terms of current, voltage, frequency, and so on. The natural causes of poor power quality are mainly faults, lightning, weather conditions. However, loads or system operations are the man-made ones. The causes related to the loads are nonlinear loads such as saturating transformers and other electrical machines, or loads with solid-state controllers such as vapor lamp-based lighting systems.

The power quality problems affect all concerned utilities, customers, and manufacturers directly or indirectly in terms of major financial losses due to interruption of process, equipment damage, production loss, wastage of raw material, loss of important data, and so on. There are many instances and applications such as automated industrial processes, namely, semiconductor manufacturing, pharmaceutical, glass industries, and banking, where even a small voltage dip/sag causes interruption of process for several hours, wastage of raw material, and so on. Some power quality problems affect the protection systems and result in maloperation of protective devices. These interrupt many operations and processes in the industries and other establishments. These also affect many types of measuring instruments and metering of the various quantities such as voltage, current, power, and energy. Moreover, these problems affect the monitoring systems in much critical, important, emergency, vital, and costly equipment [2].

The EN 50160 standard [3] indicates that there is no such limitation on the voltage values in the IEEE 1159 [4] standard power system, while concentrating on the voltage characteristics of the low and medium voltage grids. A few seconds of transient voltage disturbances are classified in the IEEE 1250 standard [5]. Although the same voltage drop event is based on the same standard between EN 50160 and IEEE 1159 standards, the amplitude of the event is defined differently in these standards. This is shown in Table 1 for both standards [6]. This classification method, based on the magnitude and duration of events in the electricity grid, has several advantages and drawbacks. When this method is used, the following items are expressed [2]:

The effective value (rms) of the voltage at the time of the event is not constant, which may lead to an uncertainty when describing the amplitude and duration of the event. Rapid events that are shorter than a period cannot be defined very well because the value of the voltage may not be fully calculated. Repeated events can give erroneous results. In this case, the number of events may be missing or overestimated [7].

The voltage will be reduced to 0,1 pu or less and will focus on immediate events up to 1 second. Short interruptions and voltage drops events are characterized by this amplitude and duration [1]. These events mainly concern short circuits in the electricity grid.

In this study, the answers to the following questions will be tried to be answered according to the actual field / measurements.

- Why does a distribution grid fail?

- What is the effect of grid faults on the production facility?

- Is there a difference between organizing industry connection, direct $154 \mathrm{kV}$ system connection, distribution system output connection? 
- Is it necessary to link the national grid to the same criteria for all installations?

- What is needed to ensure the same reliability?

- Does the load characteristic affect the connection point selection?

\section{Investigation of the Grid Events}

Grid events have been effectively introduced in the literature and standards [8]. In this respect, various studies including measurement and long-term studies have been carried out in countries such as USA, France [6]. In Turkey, there is no study which will contribute to the national system based on the actual measurement results, which is reflected in the literature in this respect. This system, which is thought to be radial, seems to be efficient, providing very effective solutions when examining the various regions of our country. However, it is seen that this positive effect on the transmission system does not continue in the distribution system in the same way due to the structural differences, and therefore some obligations like measurement, recording have to be applied and and not standardized.

3 years events were recorded according to EN 50160 standard. These are based on short and long interruptions, voltage sags and swells that fall below $0.9-1.1 \mathrm{pu}$, which is considered to lead to production failures. Voltage unbalance, flicker and harmonics will not be considered here. Plants' locations are seen in Figure 1. Distribution companies are different for all locations.

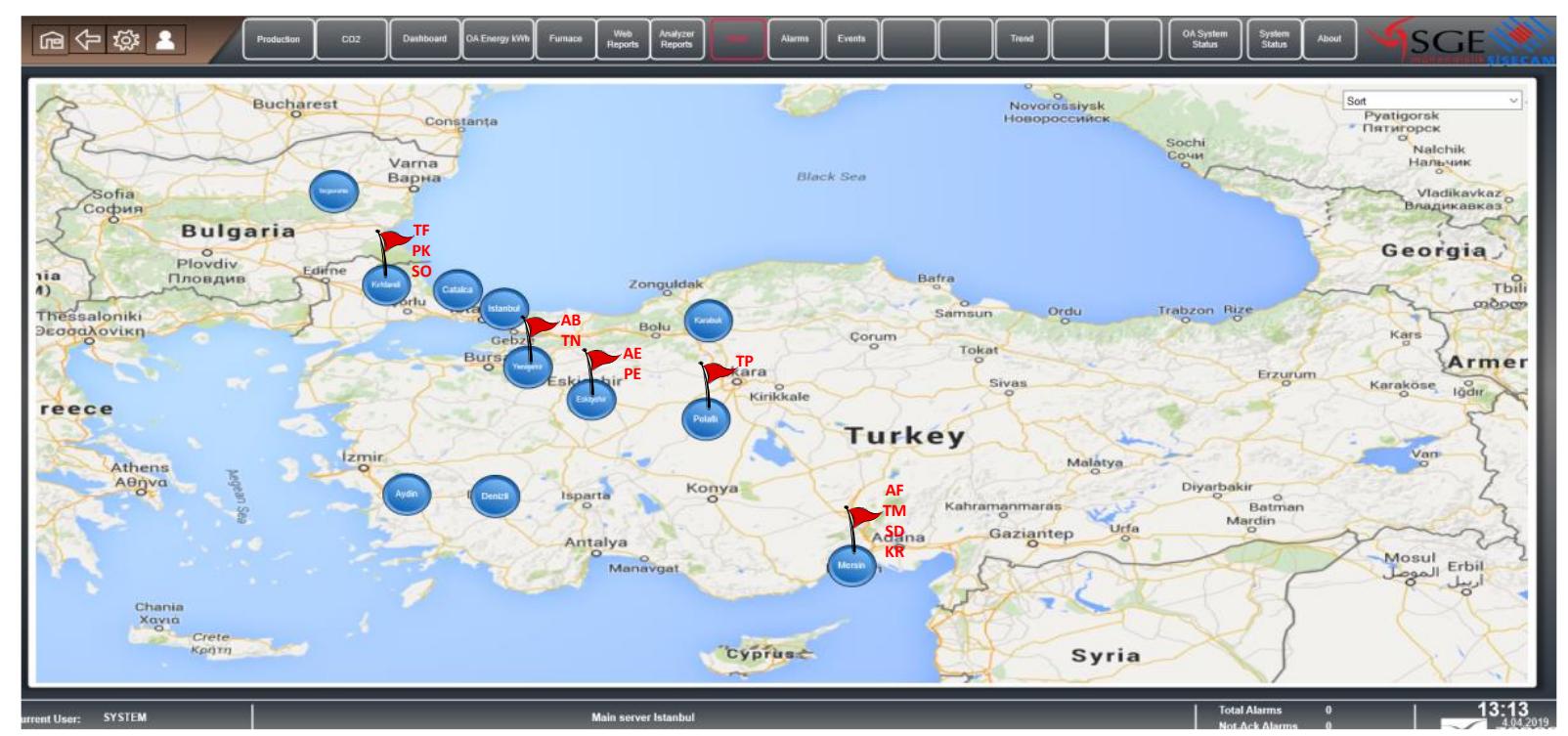

Figure. 1. Distributed localized industrial plants on Turkish map

The power quality (PQ) problems due to power distribution systems's disturbances are not just the power quality problems but also affect the energy efficiency of the plant. As far as energy efficiency is concerned in an industrial plant power quality events will create negative sequence components causing power losses in conductors and electrical motors and malfunctioning of entire system like relays. Even more, these they can damage the system components [9].

There are major reasons for the concerning events: Newer load equipment with microprocessor based controls and power electronic devices is more sensitive to PQ variations. Adjustable speed motor drives and shunt capacitors for power correction to reduce losses need to high overall power system efficiency. System capacity has impact on increasing reliability. 
Now, end users have an increased awareness of power quality events by monitoring. End users are becoming better informed about such issues as interruptions, sags, switching transients and need power quality issues to be improved. Integrated processes and connections to grid mean that the failure of any plants has much more impact on grid.

\subsection{Voltage Interruptions}

The origins of the voltage interruptions in general are "faults" which caused by grid or industrial plants and broken connection pieces. An interruption is the supply voltage or load current decreases to less than 0.1 pu for a period of time less than 3 minutes. Interruptions can be the result of power system faults, equipment failures, and control malfunctions and misoperation. The interruptions are measured by duration of the voltage magnitude less than 1 percent. The duration of an interruption due to a fault on the grid is determined by the operating time of utility and plant protective devices [10]. Reclosing and/or delayed reclosing of the protective devices can limit the interruption caused by a fault. The duration of an interruption due to equipment malfunctions or loose connections can be irregular.

Table 1. Definion of Interruptions.

\begin{tabular}{lllll}
\hline Standard & Definition & Magnitude & Duration & Applicability \\
\hline EN 50160 & Short interruption & $<\% 1$ & $<3$ minutes & $\begin{array}{l}\text { LV and MV } \\
(<35 \mathrm{kV})\end{array}$ \\
$\begin{array}{l}\text { IEEE Std 1159- } \\
1995\end{array}$ & $\begin{array}{l}\text { Momentary } \\
\text { interruption }\end{array}$ & $<\% 10$ & $10 \mathrm{~ms}-3 \mathrm{sec}$ & $\mathrm{LV}, \mathrm{MV}, \mathrm{HV}$ \\
$\begin{array}{l}\text { Instantenous } \\
\text { IEEE Std 1250- }\end{array}$ & $\begin{array}{l}\text { interruption } \\
\text { Momentary }\end{array}$ & $\begin{array}{l}\text { Complete loss of } \\
\text { voltage }\end{array}$ & $10 \mathrm{~ms}-0,5 \mathrm{sec}$ & $\mathrm{LV}, \mathrm{MV}, \mathrm{HV}$ \\
& $\begin{array}{l}\text { interruption } \\
\text { Tags }\end{array}$ & $10 \mathrm{~ms}-2 \mathrm{sec}$ & LV, MV, HV \\
\hline
\end{tabular}

Tables 2-3-4 are numbers of event occurred. These PQ events are monitored by localized sensitive equipment.

Table 2. 2016 Events' Statistics.

\begin{tabular}{llllllll}
\hline Plant & Year & $\begin{array}{l}\text { Recording } \\
\text { duration } \\
\text { (Hours/Year) }\end{array}$ & $\begin{array}{l}\text { Short } \\
\text { Interruptions } \\
\text { of the supply } \\
\text { voltage }\end{array}$ & $\begin{array}{l}\text { Long } \\
\text { Interruptions } \\
\text { of the supply } \\
\text { voltage }\end{array}$ & $\begin{array}{l}\text { Supply } \\
\text { voltage } \\
\text { dip }\end{array}$ & $\begin{array}{l}\text { Supply } \\
\text { voltage } \\
\text { swell }\end{array}$ & $\begin{array}{l}\text { Sum of all } \\
\text { events }\end{array}$ \\
\hline AB & 2016 & 8760 & 0 & 4 & 144 & 8 & 156 \\
AE & 2016 & 8760 & 0 & 1 & 98 & 7 & 106 \\
AF & 2016 & 8760 & 1 & 3 & 59 & 1 & 64 \\
PE & 2016 & 8760 & 4 & 4 & 102 & 13 & 123 \\
PK & 2016 & 8760 & 0 & 2 & 387 & 394 & 783 \\
TF & 2016 & 8516 & 0 & 0 & 335 & 358 & 693 \\
TM & 2016 & 8760 & 0 & 1 & 215 & 59 & 275 \\
TN & 2016 & 8760 & 0 & 2 & 148 & 14 & 164 \\
TP & 2016 & 8760 & 0 & 7 & 1588 & 1243 & 2838 \\
SO & 2016 & 8760 & 2 & 9 & 409 & 408 & 828 \\
SD & 2016 & 8760 & 9 & 14 & 95 & 28 & 146 \\
KR & 2016 & 8760 & 3 & 0 & 2 & 0 & 5 \\
\hline
\end{tabular}


Table 3. 2017 Events' Statistics.

\begin{tabular}{llllllll}
\hline Plant & Year & $\begin{array}{l}\text { Recording } \\
\text { duration } \\
\text { (Hours/Year) }\end{array}$ & $\begin{array}{l}\text { Short } \\
\text { Interruptions } \\
\text { of the supply } \\
\text { voltage }\end{array}$ & $\begin{array}{l}\text { Long } \\
\text { Interruptions } \\
\text { of the supply } \\
\text { voltage }\end{array}$ & $\begin{array}{l}\text { Supply } \\
\text { voltage } \\
\text { dip }\end{array}$ & $\begin{array}{l}\text { Supply } \\
\text { voltage } \\
\text { swell }\end{array}$ & $\begin{array}{l}\text { Sum of all } \\
\text { events }\end{array}$ \\
\hline AB & 2017 & 8760 & 1 & 4 & 102 & 2 & 109 \\
AE & 2017 & 8760 & 0 & 0 & 64 & 6 & 70 \\
AF & 2017 & 7392 & 2 & 1 & 31 & 2 & 36 \\
PE & 2017 & 8760 & 1 & 2 & 65 & 6 & 74 \\
PK & 2017 & 8760 & 1 & 4 & 348 & 351 & 704 \\
TF & 2017 & 4560 & 2 & 1 & 184 & 177 & 364 \\
TM & 2017 & 8760 & 1 & 1 & 272 & 132 & 406 \\
TN & 2017 & 8760 & 0 & 0 & 7 & 0 & 7 \\
TP & 2017 & 8760 & 28 & 8 & 898 & 522 & 1456 \\
SO & 2017 & 8760 & 0 & 11 & 357 & 355 & 723 \\
SD & 2017 & 8760 & 1 & 7 & 79 & 1 & 88 \\
KR & 2017 & 8760 & 1 & 7 & 238 & 1 & 247 \\
\hline
\end{tabular}

Table 4. 2018 Events' Statistics.

\begin{tabular}{llllllll}
\hline Plant & Year & $\begin{array}{l}\text { Recording } \\
\text { duration } \\
\text { (Hours/Year) }\end{array}$ & $\begin{array}{l}\text { Short } \\
\text { Interruptions } \\
\text { of the supply } \\
\text { voltage }\end{array}$ & $\begin{array}{l}\text { Long } \\
\text { Interruptions } \\
\text { of the supply } \\
\text { voltage }\end{array}$ & $\begin{array}{l}\text { Supply } \\
\text { voltage } \\
\text { dip }\end{array}$ & $\begin{array}{l}\text { Supply } \\
\text { voltage } \\
\text { swell }\end{array}$ & $\begin{array}{l}\text { Sum of all } \\
\text { events }\end{array}$ \\
\hline AB & 2018 & 8760 & 0 & 1 & 102 & 0 & 103 \\
AE & 2018 & 8760 & 0 & 9 & 185 & 19 & 213 \\
AF & 2018 & 8760 & 1 & 3 & 23 & 2 & 29 \\
PE & 2018 & 6744 & 2 & 8 & 185 & 20 & 215 \\
PK & 2018 & 8760 & 0 & 3 & 491 & 513 & 1007 \\
TF & 2018 & 8760 & 2 & 4 & 633 & 661 & 1300 \\
TM & 2018 & 8760 & 0 & 3 & 175 & 42 & 220 \\
TN & 2018 & 8396 & 4 & 1 & 13 & 4 & 22 \\
TP & 2018 & 8760 & 2 & 7 & 1092 & 867 & 1968 \\
SO & 2018 & 8760 & 0 & 10 & 659 & 672 & 1341 \\
SD & 2018 & 8760 & 0 & 3 & 55 & 0 & 58 \\
KR & 2018 & 8760 & 0 & 3 & 34 & 0 & 37 \\
\hline
\end{tabular}

AE plant amplitude - duration statistics data is given Table 5. These tables are available for all but not will be given more for other plants and years. 
Table 5. Events' Amplitude and Times Characteristics

\begin{tabular}{|c|c|c|c|c|c|c|}
\hline \multirow{2}{*}{$\begin{array}{l}\text { Res. voltage } \\
\text { u (\%) }\end{array}$} & \multirow[b]{2}{*}{$0.01 \leq \mathrm{t} \leq 0.2$} & \multirow[b]{2}{*}{$0.2 \leq \mathrm{t} \leq 0.5$} & \multicolumn{3}{|l|}{ Duration (s) } & \multirow[b]{2}{*}{$t>60$} \\
\hline & & & $0.5 \leq \mathrm{t} \leq 1$ & $1 \leq \mathrm{t} \leq 5$ & $5 \leq \mathrm{t} \leq 60$ & \\
\hline $90 \geq \mathrm{u} \geq 80$ & 102 & 5 & 7 & 5 & 0 & 0 \\
\hline $80 \geq \mathrm{u} \geq 70$ & 22 & 4 & 6 & 0 & 0 & 0 \\
\hline $70 \geq \mathrm{u} \geq 40$ & 14 & 0 & 1 & 0 & 0 & 0 \\
\hline $40 \geq u \geq 5$ & 16 & 1 & 0 & 1 & 1 & 0 \\
\hline $5 \geq \mathrm{u}$ & 0 & 0 & 0 & 0 & 0 & 9 \\
\hline
\end{tabular}

\subsection{Voltage Sags}

Table 6 shows voltage sags terminology as standardized. The reason of voltage sags may be short circuits, overloads, and starting of large motors. Distance to fault, line/cable characteristics, transformers connection, grid status, short circuit impedance, etc. are deterministic parameters for voltage sags.

Table 6. Definion of Voltage Sags

\begin{tabular}{|c|c|c|c|}
\hline Standard & Magnitude & Duration & Applicability \\
\hline EN 50160 & $\% 1-90 \%$ & 0.5 cycles to $1 \mathrm{~min}$ & $\begin{array}{l}\mathrm{LV} \text { and } \mathrm{MV} \\
\text { (up to }<35 \mathrm{kV} \text { ) }\end{array}$ \\
\hline IEEE Std 1159-1995 & $\% 10-90 \%$ & 0.5 cycles to $1 \mathrm{~min}$ & $\mathrm{LV}, \mathrm{MV}, \mathrm{HV}$ \\
\hline IEEE Std 1250-1995 & $\begin{array}{l}\text { Reduction of } \\
\text { voltage }\end{array}$ & 0.5 cycles to few seconds & $\mathrm{LV}, \mathrm{MV}, \mathrm{HV}$ \\
\hline
\end{tabular}

As seen in Table 2-3-4, there are huge amount voltage sags that are uncontrollable.

This survey of power quality has run for 3 years 12 industrial plants which have been monitored at their point of common coupling. Some plants are connected to the grid at the same bar but different cubicles.

Power quality intensity (all events occurred one day/one year) is seen in Table 7.

Table 7. Power Quality Intensity

\begin{tabular}{lllll}
\hline PQ Event Intensity & 2016 & 2017 & 2018 & 3 Years Average \\
\hline AB & 0,018 & 0,012 & 0,012 & 0,014 \\
AE & 0,012 & 0,008 & 0,024 & 0,015 \\
AF & 0,007 & 0,005 & 0,003 & 0,005 \\
PE & 0,014 & 0,008 & 0,032 & 0,018 \\
PK & 0,089 & 0,080 & 0,115 & 0,095 \\
TF & 0,081 & 0,080 & 0,148 & 0,092 \\
TM & 0,031 & 0,046 & 0,025 & 0,034 \\
TN & 0,019 & 0,001 & 0,003 & 0,008 \\
TP & 0,324 & 0,166 & 0,225 & 0,238 \\
SO & 0,095 & 0,083 & 0,153 & 0,110 \\
SD & 0,017 & 0,010 & 0,007 & 0,011 \\
KR & 0,001 & 0,028 & 0,004 & 0,011 \\
\hline
\end{tabular}


Industrial plants connections to the national grid/substations are defined in Table 8.

Table 8. Substation Connection With Electrical Parameters

\begin{tabular}{lllll}
\hline $\begin{array}{l}\text { Ind. Plant } \\
\text { Code }\end{array}$ & City & $\begin{array}{l}154 / 36 \mathrm{kV} \\
\text { Substation Name }\end{array}$ & $\begin{array}{l}\text { 3 phase } \\
\text { shortcircuit }[\mathrm{kA}]\end{array}$ & $\begin{array}{l}\text { 1 phase - earth } \\
\text { shortcircuit [kA] }\end{array}$ \\
\hline AB & Yenisehir & Yenisehir & 8,93 & 5,51 \\
AE & Eskisehir & Eskisehir 3 & 20,39 & 15,72 \\
AF & Mersin & Yakakoy & 13,67 & 9,94 \\
PE & Eskisehir & Eskisehir 3 & 20,39 & 15,72 \\
PK & Kirklareli & Buyuk Karistiran & 16,59 & 12,06 \\
TF & Kirklareli & Buyuk Karistiran & 16,59 & 12,06 \\
TM & Mersin & Nacarli & 19,87 & 15,81 \\
TN & Yenisehir & Yenisehir & 8,93 & 5,51 \\
TP & Polatli & Beylikkopru & 5,20 & 3,30 \\
SO & Kirklareli & Buyuk Karistiran & 16,59 & 12,06 \\
SD & Mersin & Mersin 2 & 13,50 & 10,42 \\
KR & Mersin & Mersin 3 & 13,50 & 10,42 \\
\hline
\end{tabular}

Table 8 is of Turkish grid operator, Turkish Electricity Transmission Company (TEIAS), data. It is seen here that, 3 phase and 1 phase-earth shortcircuits' ratios are correlated with each other. However, power quality intensity given above does not correspond to this. Some special situations must be investigated for reliability analysis. Table 9 is of same substation connections of industrial plants.

Table 9. Local Categorization

\begin{tabular}{llll}
\hline Ind. Plant Code & City & $\begin{array}{l}\text { 154/36 kV } \\
\text { Substation Name }\end{array}$ & $\begin{array}{l}\text { PQ Intensity } \\
\text { 3 Years Average }\end{array}$ \\
\hline AB & Yenisehir & Yenisehir & 0,014 \\
TN & Yenisehir & Yenisehir & 0,008 \\
AE & Eskisehir & Eskisehir 3 & 0,015 \\
PE & Eskisehir & Eskisehir 3 & 0,018 \\
PK & Kirklareli & Buyuk Karistiran & 0,095 \\
TF & Kirklareli & Buyuk Karistiran & 0,092 \\
SO & Kirklareli & Buyuk Karistiran & 0,110 \\
AF & Mersin & Yakakoy & 0,005 \\
TM & Mersin & Nacarli & 0,034 \\
SD & Mersin & Mersin 2 & 0,011 \\
KR & Mersin & Mersin 2 & 0,011 \\
TP & Polatli & Beylikkopru & 0,238 \\
\hline
\end{tabular}

There is 5 area including 7 substation and 12 plants. The second best value is, 0,008 by TN and the second worst is 0,110 by SO. Reliabilities (R) by this assumption are $99.2 \%$ and $89.00 \%$ sequentially. By using Bernoulli (Binomial) equation, for $99.20 \%$ Table 10 is created for reliability map according to industrial plants connected to substations. 
Reliability is the ability of the power system to supply energy within accepted standards and in the amount desired. For industril plants, the availability Table 10 is often stated as being the adopted reliability.

Table 10. Reliability Impacts of New Plants/Cubicles

\begin{tabular}{llllllllll}
\hline $\mathrm{n}$ & 1 & 2 & 3 & 4 & 5 & 6 & 7 & 8 & 9 \\
\hline $\mathrm{R}$ & 0,9920 & 0,9841 & 0,9762 & 0,9684 & 0,9606 & 0,9529 & 0,9453 & 0,9377 & 0,9303 \\
\hline
\end{tabular}

From a grid service perspective, a power supply is delivered with a reliability in the range of 1 to 2 column, while end customers typically experience a low reliable power, in the range of 8 to 9 ones. Reliability is measured using various indices characterising duration, and magnitude of adverse effects on the power-quality issues (such as voltage-dip and swell disturbances) that are becoming increasingly significant in sustainable production. For critical-process information services contemporary thoughts on this topic are quite differently focused; modern power-system reliability relates more reliability, quality, security and redundancy.

\section{Conclusion and Suggestions}

In this study, the data obtained for the link states from different connection points to the national grid in different regions of our country are examined.

Based on the presented records regarding events on the electrical grid can be drawn the following conclusions:

- The industrial plants that have individual feeder at the substation and less plants have good reliability that is the most important for product quality.

- The installations connected to the Organize Industrial Zone (OIZ) seem to have the second best connection.

- Industrial plants connected to the distribution system feeders have the worst conditions.

- In the same busbar, as the plant itself collapses, the voltage decreases to less than $0.5 \mathrm{pu}$ voltage amplitude that causes the other plants collapse and loss of production.

- In this case, it is important to standardize the maintenance that the facilities have done or have done. This is because the failures in the distribution seem to originate mainly from the facilities connected to the busbar.

- It is especially important that the transformer center and the OIZ or the individual feeder plants are fed by double circuit. Man-made failures of long-distance events leave the whole system without backup.

- It will be beneficial to standardize this distance and to provide $154 \mathrm{kV}$ if necessary.

- The definition of consumer and producer linkage published in the Official Gazette dated 30.07.2016 should be assessed taking into consideration the load characteristics and dynamics. For example, a facility with a $5 \mathrm{MW}$ moment load input / output, such as the SO, should not be considered as a facility with a total load of $2.5 \mathrm{MW}$.

- As the number of consumers connected to the bus increases, it is seen that the failures experienced are also linear. In this case, the facilities do not have the same service quality. There is a difference between the power quality provided in Mersin and the power quality provided in Thrace.

- The fact that transformer substations have standard power and number of consumers will increase the quality of the power.

- It appears that there are a significant number of voltage surges in the grid.

The national grid is integrated with producers, transmitters, distributors and consumers. The negativity experienced in one of these will adversely affect the others. 
Equipping the factories with a monitoring system that allows the evaluation of the quality of the power in the standard building, such as the meters that are the basis for the invoice, will be beneficial in terms of prioritizing system improvements.

\section{References}

[1] Bollen M. H. J., IEEE Press Series on Power Engineering, 1, IEEE, New York, 2000.

[2] Singh B., Chandra A., Al-Haddad K., Power Quality, Wiley, United Kingdom, 2015.

[3] EN 50160, Voltage characteristics of electricity supplied by public distribution systems, European Norm, Brussels, 2000.

[4] IEEE 1159, Recommended Practice for Monitoring Electric Power Quality, The Institute of Electrical and Electronics Engineers, New York, 1995.

[5] IEEE 1250, Guide for service to equipment sensitive to momentary voltage disturbances, The Institute of Electrical and Electronics Engineers, New York, 1995.

[6] Kılıç L., Trakya bölgesindeki özel bir santralın geçici durum kararlılık kriterlerinin belirlenmesi, Doktora Tezi, Kocaeli Üniversitesi, 2015.

[7] Iov F., Hansen A.D., Sorensen P., Cutululis N. A., Mapping of Grid Faults and Grid Codes, Aalborg University, Riso National Laboratory, Denmark, July 2007.

[8] Dugan R.C., McGranaghan M.F., Santoso S., Beaty H.W., Electrical Power Systems Quality, McGraw Hill, copyright@2004.

[9] Munoz A. M., Power Quality, Springer, Spain, 2007.

[10] Kusko A., Thompson M. T., Power Quality in Electrical Systems, McGraw Hill, copyright@2007. 